\title{
A CLINICAL AND EXPERIMENTAL STUDY OF THE STABILITY OF COLLOID OSMOTIC PRESSURE OF SERUM PROTEIN
}

\author{
BY KINTARO YANAGI 1, 2 \\ (From the Department of Medicine of the University of Rochester School of Medicine and \\ Dentistry, and the Medical Clinic of the Strong Memorial and Rochester \\ Municipal Hospitals, Rochester, New York)
}

(Received for publication July 8, 1935)

The work of earlier investigators, Govaerts (1), Baráth (2), Cope (3), Peters et al. (4) and Kylin (5) has given the impression that the colloid osmotic pressure is not only lowered with decrease in serum protein but its specific pressure (pressure per unit of protein) is also diminished. The lowering of specific pressure has usually been related to a greater decrease in the albumin fraction of the proteins than that of the globulin, so that the $A: G$ ratio becomes reduced or inverted. However, in all of these reports, the pressure readings were taken at the end of twentyfour hours or longer, and probably do not represent the highest point on the pressure curve. Wells et al. (6) have recently discussed the validity of determining the colloid osmotic pressure by a rapid method devised by them. They also presented data on hypoproteinemic sera which gave low specific pressures, and referred to the fact that the pressure in many cases after rising to some extent began to fall within a few hours. They attempt to explain this by putrefactive change or molecular aggregation of serum protein $(6,7)$. In the method reported here the possibility of contamination of the serum with bacteria has been excluded. Measurement of the colloid osmotic pressure of the serum proteins of nephrotic patients has revealed a decrease in the stability of the pressure readings in those instances where the concentration of proteins approached the edema level. In most of the cases the maximum pressure was obtained in three to five hours, and thereafter began to fall gradually. This was in marked contrast to the prolonged plateau of nearly constant pressure observed when the concentration of protein was normal.

While good correlation was observed between

1 Travelling Fellow of the Rockefeller Foundation.

2 Instructor in Medicine, Medical Faculty, Tokyo Imperial University, Japan. the maximum pressure and the content of total protein, there was little evidence of correlation between the ratio of albumin: globulin and the maximum pressure. The data show that the pressure per gram of protein may actually be somewhat greater when the serum proteins are low than when their concentration falls within the normal range.

\section{METHOD}

Blood was taken with the least possible stasis from the antecubital vein, while the patient was recumbent in bed. Precautions were observed to insure sterility of the serum during collection of the blood and during the subsequent centrifugation and separation of the serum from the clot.

The specific gravity of the serum was determined by Hammerschlag's method (8), the refractive index by Abbe's refractometer at constant room temperature of $23^{\circ} \mathrm{C}$. The total content of protein, albumin and globulin were determined by Howe's method using $1 \mathrm{cc}$. of serum for each sample (9). The determination of colloid osmotic pressure was carried out with the apparatus devised by Fellows (10), similar in principle to that of Verney (11). The osmometer has the advantage that the osmotic pressure can be followed at any desired interval of time. Some modifications were made on the instrument itself, the stopcock being removed from its original position to the upper end of the graduated portion of the capillary tube, and the hole on the side of the osmometer tube being omitted in order to minimize the danger of any leakage of serum.

As the dialyzing agent a modified Ringer's solution consisting of 0.8 per cent sodium chloride and 0.042 per cent potassium chloride was used. The osmometer was inclosed in a large glass tube for sterilization, and autoclaved for 15 to 20 
minutes at $120^{\circ} \mathrm{C}$. When ready for use, the osmometer was filled with sterile serum and immersed in a water bath kept constantly at $30^{\circ} \mathrm{C}$. by an electrical thermostat and a mechanical stirrer. Care was taken to maintain the room temperature at approximately $23^{\circ} \mathrm{C}$.

The pressure reading in the manometer was noted every half hour or every hour, adjusting the meniscus of the serum to the same point with the aid of a microscopic lens. During the night when observations were omitted, the stopcock was closed in order to cut the connection to the manometer and yet permit equilibration to continue without any gross change in the reading of the meniscus. In the morning the stopcock was opened, the manometer was readjusted, and the readings were continued. In order to calculate the osmotic pressure the specific gravity of both the serum and the solution in the manometer (12 per cent sodium glycocholate in water) were taken into consideration.

Routine examinations for possible sources of error in the apparatus were made. Sterilization produced no change in the permeability of the membrane (DuPont number 300 plain transparent cellophane). The difference in time required for equilibration of various concentrations of diffusi- ble substances was found to have no effect on the final result. The hydrostatic pressure of the liquid in the capillary tube above the cup holding the membrane and the capillary attraction were determined, and appropriate corrections were made in the computations of pressures. Duplicate or triplicate determinations were done except in a few cases where material was insufficient. The results usually agreed within ten millimeters of water with a maximum variation of fifteen millimeters in some cases.

\section{RESULTS}

Colloid osmotic pressures of serum proteins in normal persons determined in this laboratory and previously reported by Fellows (10) show values ranging from 321 to 380 millimeters of water with protein content varying between 6.32 and 6.81 per cent. Further data obtained on the serum of normal dogs and from patients whose total serum proteins were within normal limits are given in Table I.

As may be noted, the specific gravity of the serum remains quite constant over a wide range of protein content, although there is some tendency for it to vary in the same direction as the concentration of protein (see also Table II).

TABLE I

Colloid osmotic pressure of normal stability

\begin{tabular}{|c|c|c|c|c|c|c|c|c|c|}
\hline Name & $\begin{array}{l}\text { Age } \\
\text { and } \\
\text { sex }\end{array}$ & $\begin{array}{l}\text { Specific } \\
\text { gravity }\end{array}$ & $\begin{array}{c}\text { Total } \\
\text { protein }\end{array}$ & Albumin & Globulin & $\underset{\text { ratio }}{\mathbf{A}: \mathbf{G}}$ & $\begin{array}{c}\text { Total } \\
\text { pressure }\end{array}$ & $\begin{array}{l}\text { Specific } \\
\text { pressure }\end{array}$ & Remarks \\
\hline & $\begin{array}{c}\text { years } \\
39\end{array}$ & & per cent & per cent & per cent & & $m m . H_{2} \mathrm{O}$ & $m m . H=O$ & \\
\hline I.G... & $0^{3}$ & 1.032 & 7.04 & 5.31 & 1.73 & 3.07 & 330.0 & 47.0 & Myxedema \\
\hline H.D. . & $\begin{array}{c}20 \\
9 \\
9\end{array}$ & 1.032 & 6.55 & 4.84 & 1.81 & 2.76 & 358.0 & 54.0 & Chronic hemorrhagic nephritis \\
\hline M.P. . & 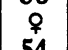 & 1.032 & 6.36 & 4.18 & 2.18 & 1.92 & 332.0 & 52.2 & Mitral stenosis \\
\hline F.D. . & 8 & 1.030 & 6.28 & 4.15 & 2.13 & 1.94 & 304.5 & 48.5 & Arteriosclerosis \\
\hline E.B.. & $\begin{array}{l}2 \\
2 \\
2\end{array}$ & 1.031 & 6.20 & 3.43 & 2.77 & 1.24 & 279.4 & 45.0 & Chronic hemorrhagic nephritis \\
\hline W.A. . & $\begin{array}{ll}30 \\
8\end{array}$ & 1.031 & 5.81 & 3.88 & 1.93 & 2.01 & 290.9 & 50.1 & Cardiac insufficiency \\
\hline $\begin{array}{l}\text { A.N. . } \\
\text { Dog } 1 \\
\text { Dog } 1 \\
\text { Dog } 2 \\
\text { Dog 2 } \\
\text { Dog } 3 \\
\text { Dog } 3\end{array}$ & $\begin{array}{l}q \\
q \\
q \\
q \\
q \\
q \\
q \\
q \\
q\end{array}$ & $\begin{array}{l}1.031 \\
1.031 \\
1.031 \\
1.031 \\
1.031 \\
1.031 \\
1.030\end{array}$ & $\begin{array}{l}5.56 \\
6.17 \\
6.16 \\
6.08 \\
5.74 \\
5.78 \\
5.55\end{array}$ & $\begin{array}{l}3.48 \\
4.31 \\
4.28 \\
4.25 \\
4.24 \\
3.88 \\
3.86\end{array}$ & $\begin{array}{l}2.08 \\
1.87 \\
1.88 \\
1.83 \\
1.50 \\
1.90 \\
1.64\end{array}$ & $\begin{array}{l}1.67 \\
2.30 \\
2.27 \\
2.32 \\
2.82 \\
2.04 \\
2.35\end{array}$ & $\begin{array}{l}279.0 \\
323.1 \\
312.3 \\
308.1 \\
305.1 \\
271.5 \\
272.5\end{array}$ & $\begin{array}{l}50.2 \\
52.3 \\
50.7 \\
50.8 \\
53.2 \\
47.0 \\
49.6\end{array}$ & $\begin{array}{l}\text { Arteriosclerosis } \\
\text { Normal } \\
\text { Normal } \\
\text { Normal } \\
\text { Normal } \\
\text { Normal } \\
\text { Normal }\end{array}$ \\
\hline \multicolumn{8}{|r|}{ Average } & 49.9 & \\
\hline
\end{tabular}


TABLE II

Colloid osmotic pressure of reduced stability in patients with low serum protein

(Through the courtesy of Dr. S. W. Clausen 3 pediatric cases are included in this group.)

\begin{tabular}{|c|c|c|c|c|c|c|c|c|c|c|}
\hline \multirow{2}{*}{ Name } & \multirow{2}{*}{$\begin{array}{l}\text { Age } \\
\text { and } \\
\text { sex }\end{array}$} & \multirow{2}{*}{$\begin{array}{l}\text { Specific } \\
\text { gravity }\end{array}$} & \multirow{2}{*}{$\begin{array}{c}\text { Total } \\
\text { protein }\end{array}$} & \multirow{2}{*}{$\begin{array}{l}\text { A : } \mathbf{G} \\
\text { ratio }\end{array}$} & \multicolumn{4}{|c|}{ Colloid osmotic pressure } & \multirow{2}{*}{ Stability } & \multirow{2}{*}{ Remarks } \\
\hline & & & & & $\begin{array}{l}\text { Highest } \\
\text { pressure }\end{array}$ & $\begin{array}{c}\text { Specific } \\
\text { pressure }\end{array}$ & \begin{tabular}{|c|} 
Lowest \\
pressure
\end{tabular} & \begin{tabular}{|c} 
Specific \\
pressure
\end{tabular} & & \\
\hline & \multirow{9}{*}{$\cdot\left[\begin{array}{c}\text { years } \\
68 \\
0 \\
08 \\
68 \\
0 \\
12 \\
0 \\
45 \\
0^{71} \\
2 \\
0^{7} \\
8 \\
0^{7} \\
23 \\
0 \\
50 \\
6\end{array}\right.$} & & per cent & & $m m . H 3 O$ & $m m . H_{2} \mathrm{O}$ & $m m . H_{2} \mathrm{O}$ & $m m . H_{5} \mathrm{O}$ & hours & \\
\hline J.S... & & 1.030 & 5.20 & 2.17 & 275.5 & 53.0 & 253.7 & 48.7 & 8 & Hypertension, cardiac insufficiency \\
\hline A.B. . & & 1.030 & 5.14 & 1.74 & 252.3 & 49.2 & 230.3 & 44.9 & 8 & Arteriosclerosis, cardiac insufficiency \\
\hline E.B. . & & 1.027 & 5.30 & 1.02 & 240.1 & 45.4 & 210.0 & 39.6 & 7 & Chronic hemorrhagic nephritis \\
\hline G.S... & & 1.026 & 5.05 & 0.63 & 221.5 & 43.9 & 195.8 & 38.8 & 6 & Lymphatic leukemia, edema \\
\hline V.N. . & & 1.026 & 4.50 & 0.88 & 192.0 & 42.7 & 138.0 & 30.7 & 6 & Nephrosis \\
\hline J.M. . & & 1.027 & 4.50 & 0.79 & 184.5 & 41.0 & 130.2 & 29.0 & 5 & Nephrosis \\
\hline J.H... & & 1.025 & 4.47 & 2.02 & 240.0 & 53.7 & 180.0 & 40.3 & 5 & Chronic nephritis \\
\hline E.W.. & & 1.025 & 3.52 & 0.91 & 209.5 & 59.4 & 122.0 & 34.7 & 4 & Carcinomatosis \\
\hline & & & & & Average & 48.5 & & 38.3 & & \\
\hline
\end{tabular}

Similar observations have been made by Weech, Snelling and Goettsch (12). The difference between the values for specific gravity given in their paper and the values obtained here may be due to the fact that in the former plasma was used and in the latter serum. Moreover, different methods were used.

Our results on the colloid osmotic pressure of serums having concentrations of protein within normal limits correspond on the whole to those reported by Baráth (2), Oelkers (13), Bonsmann (14), Tada and Nakazawa (15) and Kylin (5). Drinker and Field (17) have reported pressures for dog serum agreeing very closely with ours, especially in regard to the specific osmotic pressure of protein in normal dogs' serum. Identical types of pressure curves were obtained for human and dog sera during the time of equilibration (see Figures $1 A$ and $B$ ).

Inspection of Figure 1 shows that the pressure usually reaches a maximum within five or six hours, in eight hours at the most, and that it is maintained at this level over a period of twentyfour hours. These curves may be regarded as showing normal stability of colloid osmotic pressure of serum protein.
Changes of stability of pressure in cases of low serum protein

When the content of serum protein was lowered considerably the stability of the colloid osmotic pressure was found to be markedly reduced. Curves obtained from such sera are shown in Figure 2. The relation of reduced stability of pressure to lowered protein content was confirmed in forty determinations, all of which gave the same types of curves varying one from another only in degree of declivity. The pressure began to fall gradually as soon as its maximum height was attained, and the rate of falling seems to have been quite constant in its whole course. The height of the maximal point depended upon the total concentration of serum protein, and in cases of like protein content it was little affected by greater albumin: globulin ratios (Table III). The time at which the pressure began to fall and the rate of its fall seemed to depend on the total protein content but may also have had some relationship to the albumin: globulin ratio. In general, the higher the content of protein, the longer the period of time before the pressure began to decrease and the more slowly it fell. This relationship is shown in Figure $2 B$, in which three different cases have been compared. 

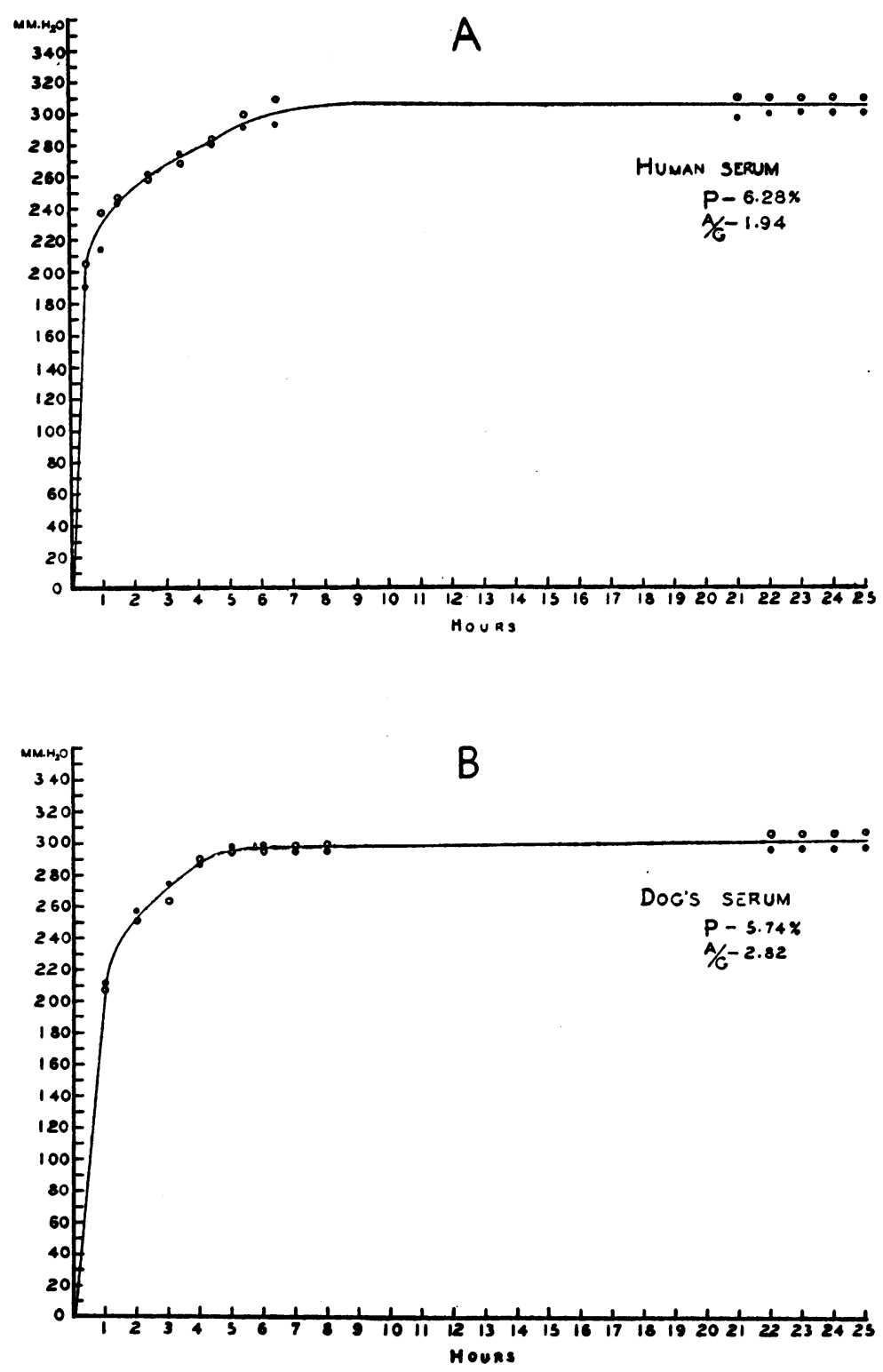

Fig. 1. The Curve of Normal Stability of Colloid Osmotic Pressure of Serum Protein in Human ( $A$ ) and in Dog $(B)$.

$P$ indicates the total protein content of serum, $A / G$ indicates the albumin-globulin ratio, dots and circles represent duplicate analyses of the same serum.

Curves 1 and 2 are from sera having almost the same content of protein, and are roughly comparable. Curve 3 rose to the highest point, due to the higher content of protein and maintained its plateau of pressure longer than did Curves 1 and 2.

This raises the question as to what should be considered the real osmotic pressure of such pro- teins. Practically; the readings of the manometers come so close to each other, even in the declining part of the curve, if read several times within an hour or two, that taking their average at the end of twenty-four hours may seem to be justifiable. Under such circumstances, the final reading of the pressure at the end of a period of twenty hours or longer gives a relatively low 

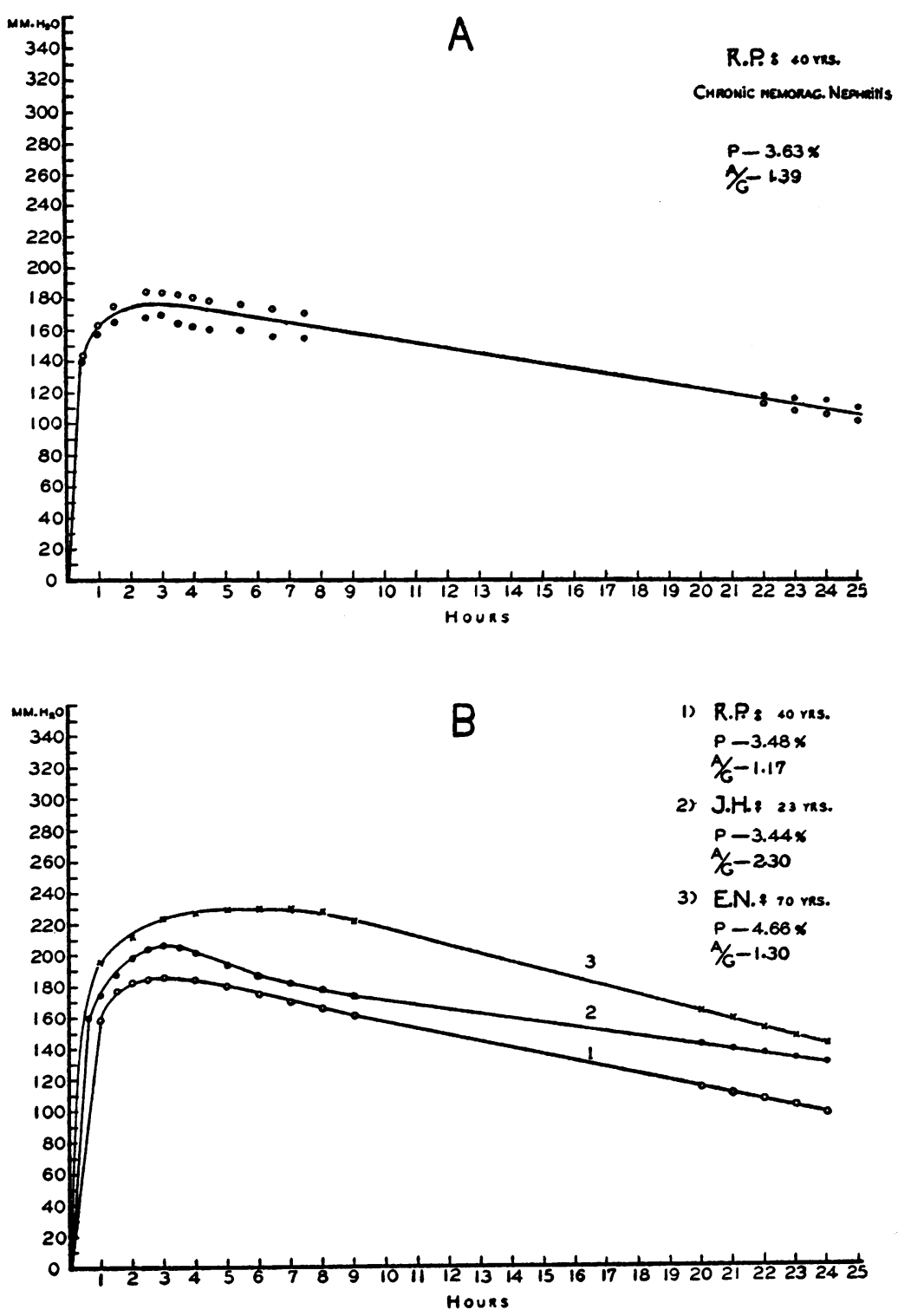

Fig. 2- $A$. The Curve of Reduced Stability of Colloid Osmotic Pressure of Serum Protein in Patient R. P.

$P$ indicates the total protein content of serum, $A / G$ indicates the albuminglobulin ratio, dots and circles represent duplicate analyses of the same serum.

Fig. 2-B. The Comparison of Curves of Reduced Stability of Colloid Osmotic Pressure in Different Patients.

Each point represents the average of duplicate determinations.

value for both the total and specific pressures. On the other hand, the average of two or three readings at short intervals of time at the highest part of the curve yields a value for total pressure approximating that obtained by multiplying the protein content by the average value of normal specific pressure. For instance, the average of duplicate maximum pressures of serum proteins in Figure $2 A$ were found to be 174.5 millimeters of water, the concentration of protein was 3.63 per cent, giving a specific pressure of 48 millimeters of water, which is close to our average 
TABLE III

Total and specific pressure of serum protein obtained at the highest part of pressure curve in markedly low protein cases

\begin{tabular}{|c|c|c|c|c|c|c|}
\hline Name & $\begin{array}{l}\text { Age } \\
\text { and } \\
\text { sex }\end{array}$ & $\begin{array}{c}\text { Total } \\
\text { protein }\end{array}$ & $\begin{array}{l}\mathbf{A}: \mathbf{G} \\
\text { ratio }\end{array}$ & $\begin{array}{c}\text { Total } \\
\text { pressure }\end{array}$ & $\begin{array}{l}\text { Specific } \\
\text { pressure }\end{array}$ & Remarks \\
\hline & 25 & & & & $m m . \mathrm{H}_{2} \mathrm{O}$ & \\
\hline L.R. . & 25 & 3.85 & 1.05 & 199.0 & 51.7 & $\begin{array}{l}\text { Nephrotic stage of } \\
\text { chronic hemor- } \\
\text { rhagic nephritis }\end{array}$ \\
\hline L.R. . & $0^{20}$ & 3.74 & 2.40 & 201.2 & 53.7 & $\begin{array}{l}\text { Nephrotic stage of } \\
\text { chronic hemor- } \\
\text { rhagic nephritis }\end{array}$ \\
\hline L.R. . & on & 3.71 & 1.65 & 207.0 & 55.8 & $\begin{array}{l}\text { Nephrotic stage of } \\
\text { chronic hemor- } \\
\text { rhagic nephritis }\end{array}$ \\
\hline P.B... & $\begin{array}{l}59 \\
0 \\
43\end{array}$ & 3.56 & 1.18 & 192.3 & 54.0 & Lipoid nephrosis \\
\hline M.F.. & $\begin{array}{l}6 \\
43\end{array}$ & 3.58 & 0.72 & 188.0 & 52.5 & Nephrosis \\
\hline M.F.. & $\begin{array}{l}8 \\
43\end{array}$ & 3.56 & 0.89 & 197.2 & 55.3 & Nephrosis \\
\hline M.F.. & 80 & 3.23 & 0.87 & 171.0 & 53.0 & Nephrosis \\
\hline R.P. . & $\begin{array}{l}0^{7} \\
40\end{array}$ & 3.48 & 1.17 & 182.9 & 52.5 & $\begin{array}{l}\text { Chronic hemorrhagic } \\
\text { nephritis }\end{array}$ \\
\hline R.P. . & o & 3.45 & 0.92 & 206.1 & 59.8 & $\begin{array}{l}\text { Chronic hemorrhagic } \\
\text { nephritis }\end{array}$ \\
\hline J.H... & 8 & 3.44 & 2.30 & 198.3 & $\mathbf{5 7 . 7}$ & Chronic nephritis \\
\hline \multicolumn{5}{|r|}{ Average } & 54.6 & \\
\hline
\end{tabular}

normal value of 49.9 millimeters. The average of the final readings were 110 millimeters of water as total pressure, giving a specific pressure of only 30.3 millimeters, which is comparable to the usual figure reported for hypoproteinemic sera by many workers.

\section{Change of stability of colloid osmotic pressure with change of patient's condition}

In three nephrotic patients and one with chronic hemorrhagic nephritis determinations of osmotic pressure were made at frequent intervals during the course of illness. Data are presented in Figure 3. In these charts the average pressure from duplicate determinations made at the peak of the curve has been plotted as the ordinate, and the time at which the pressure began to fall has been taken as the abscissa.

Figure $3 A$ gives data from a case of chronic hemorrhagic nephritis in the nephrotic stage. Maximum pressures were proportional to the concentration of protein in the different samples of serum. As usual with hypoproteinemia, all pressure readings were labile.

Figure $3 B$ presents data from a patient with lipoid nephrosis with slight edema, who improved steadily while under observation. The osmotic pressure increased with the increase of protein in the serum. Stability also increased as the concentration of protein increased. The last examination (Line 9) showed almost a normal curve of stability with a pressure of 270 millimeters of water and a concentration of protein of 5.39 per cent, giving a specific pressure of 50.2 millimeters. Figure $3 C$ presents a case of nephrosis with marked generalized edema. In six examinations of the serum the total proteins varied from 3.23 to 3.89 per cent with reversal of the albumin:globulin ratio. The maximum pressure varied with the protein content, and all pressure readings showed a marked and uniformly decreased stability. Figure $3 D$ presents another case of chronic hemorrhagic nephritis with low serum proteins. The curves of the osmotic pressure closely resembled those shown in Figure $3 C$, the characteristic features being low $A: G$ ratios and decreased stability.

Other data obtained from several patients with lower serum protein which have not been included in Table I or the figures will be found in Table II. As attention has already been directed to the fact that it is difficult to decide what may be the true osmotic pressure in such cases of reduced stability, two values are given, one obtained at the peak of the curve and the other at the end of twenty-four hours. The differences between the respective, total and specific pressures at these two intervals of time are frequently quite striking. Again, if one considers only the maximum pressure the specific pressure approaches the normal value. Low total proteins when combined with low $A$ : $G$ ratios seem to have been associated with the lowest pressure readings at the end of 24 hours.

Since the types of cases thus far considered include beside various nephropathies, cases of heart disease, lymphatic leukemia and carcinomatosis it seemed probable that hypoproteinemia itself rather than some specific constituent of the nephrotic serum was responsible for the lack of stability of the colloid osmotic pressure. Some experimental data in support of this hypothesis have been obtained. 

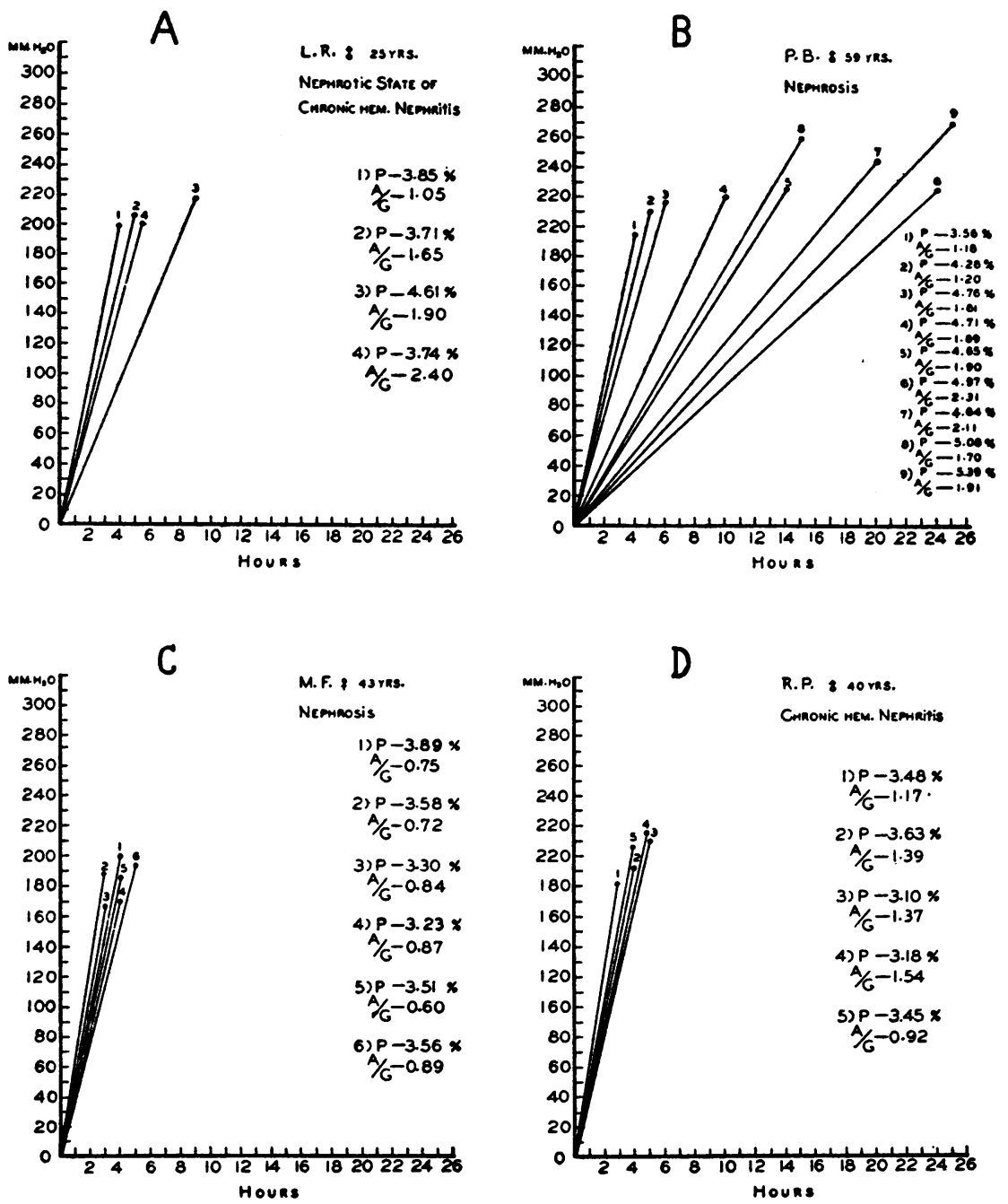

Fig. 3. The Change of Stability of Colloid Osmotic Pressure of Serum Due to Change in Concentration of Protein.

Each point represents the average of duplicate determinations and gives the maximum pressure and the maximum duration of the stable period. $P$ indicates the total protein content of serum, $A / G$ indicates the albumin : globulin ratio.

The effect of dilution of normal serum upon the stability of colloid osmotic pressure of serum protein

Govaerts (1) assumed the cause of low osmotic pressure in nephrotic patients to be due to the dilution of the blood and the fall of the specific pressure of serum proteins. Verney (11) reported that artificial dilution of serum will cause a marked fall of specific pressure of serum protein. Kylin (5) recently found that the osmotic pressure of albumin or globulin per gram per $100 \mathrm{cc}$. of water differed according to the concentration of the solution used in the determination of the pressure. When dilute solutions of these protein fractions were used, the specific pressure was far less than with higher concentration. Grönwall (16) also reported a similar relation between the specific pressure and the concentration of the serum protein.

Various dilutions of normal dog serum were prepared by the addition of 0.9 per cent saline at $\mathrm{pH}$ 6. All experimental manipulations were carried out under strictly aseptic conditions. After the osmotic pressure had been measured the protein content of the solution in the osmometer was determined by the refractometer. Although this 

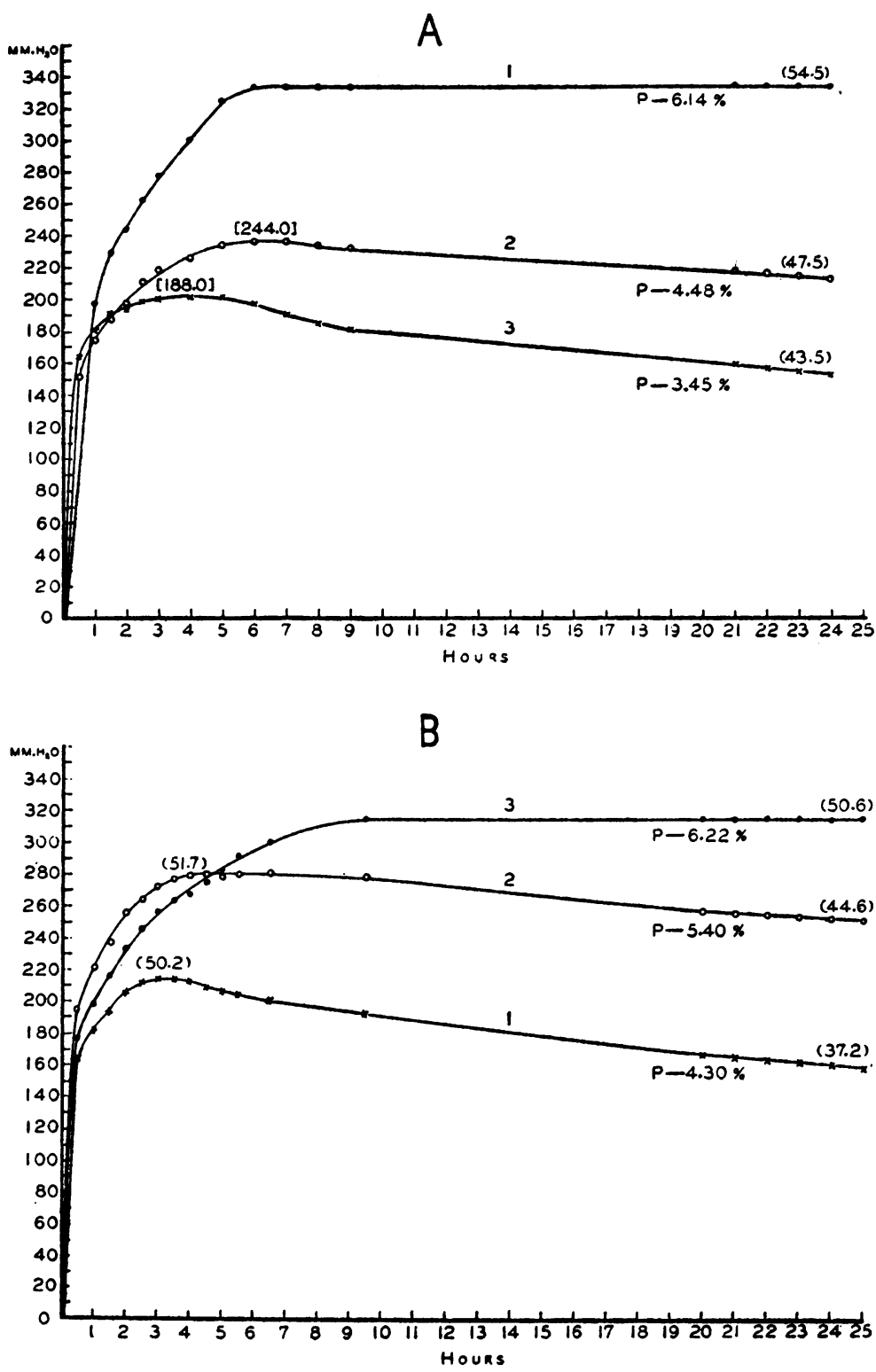

Fig. 4- $A$. The Effect of Dilution on the Stability of Collord Osmotic Pressure of Serum Protein.

Curve 1 represents the pressure of normal serum from dog. Curves 2 and 3 represent those diluted with saline solution. $P$ indicates the total protein content of serum, figures in parentheses give the specific pressure obtained at those points, figures in brackets give the predicted total pressure obtained from the protein content and the specific pressure in Curve 1.

Fig. 4-B. The Effect of Concentration on the Stability of Colloid Osmotic Pressure of Serum Protein.

Curve 1 represents the serum from a patient, with pressure of reduced stability. Curves 2 and 3 represent those specimens condensed by ultrafiltration. Figures in parentheses give the specific pressures obtained at those points, $P$ indicates the total protein content of serum. 
method of estimating concentration of protein gives a somewhat higher value than the Kjeldahl method it was found sufficiently accurate for comparative purposes.

Since similar results were obtained whenever normal serum was diluted in the manner described, the discussion has been limited to a typical case. In Figure $4 A$, Curve 1 shows the behavior of the colloid osmotic pressure of the undiluted serums while Curves 2 and 3 show the pressures obtained after sufficient saline had been added to reduce the concentration of protein to 4.48 and 3.45 per cent respectively. The pressure of the diluted serum had a distinct tendency to fall after about seven hours, the sample with 3.45 per cent of protein falling more rapidly than the less dilute sample. The undiluted serum on the other hand maintained a constant pressure from the sixth to the twenty-fourth hour. The specific pressure of the normal serum was 54.5 millimeters of water, those of the diluted sera 47.5 and 43.5 millimeters respectively when computed at the end of twenty-four hours. However, the specific pressures, computed on the basis of maximum pressure, proved to be the same in all three samples.

Experiments were also performed, using sterile ultrafiltrate ${ }^{3}$ from serum as the diluting agent. No difference was noted in the behavior of serum diluted with ultrafiltrate and that diluted with saline. The curves obtained were similar in all respects to those shown in Figure $4 A$.

Serum which had been diluted sufficiently to reduce its concentration of protein to about three or three and a half per cent frequently gave a higher specific pressure (computed from the maximum pressure) than did the undiluted serum. This tendency for lower concentration of protein to yield high specific pressures was found to hold also for abnormal sera having protein contents within the same general range (Table III).

Change of stability of osmotic pressure produced by concentration of hypoproteinemic serum

Serum from patients with hypoproteinemia was concentrated aseptically by ultrafiltration, and its colloid osmotic pressure compared with the original serum. Five experiments using samples from different patients gave similar results. The data from a single experiment are presented in Figure $4 B$. Curve 1 represents the original serum containing 4.3 per cent of protein, Curve 2 that of the serum condensed to protein concentration of 5.4 per cent, and Curve 3 that condensed to a concentration of 6.22 per cent. It will be noted that the original serum had a relatively marked reduction in the stability of the osmotic pressure while the serum condensed to 5.4 per cent had improved in its stability. Further concentration to 6.22 per cent produced a curve of normal stability. When one compares the specific pressures of these three samples, using the maximum pressure as the point of reference they are found to be almost equal to each other, namely, 50.2, 51.7 and 50.6 millimeters of water. At the end of twenty-four hours Curves 2 and 1 representing the less concentrated sera gave specific pressures of 44.6 and 37.2 millimeters of water respectively. The behavior of the serum on concentration again suggests that the principal cause of reduced stability of colloid osmotic pressure is dilution of the serum with respect to protein.

\section{DISCUSSION}

Inability to maintain a constant level of pressure for more than a few hours seems to be a characteristic of hypoproteinemic sera, whether the lowering of the concentration of protein is produced by disease or dilution of normal serum. Although the present experiments fail to provide a basis for the interpretation of this phenomenon, they demonstrate that the maximum pressure developed by such sera is about the same as the pressure derived by multiplying the observed concentration of protein by the average specific pressure of normal serum.

The falling of the pressure which was regularly observed in hypoproteinemic sera seems to have been due to an unknown change in the protein occurring several hours after it had been placed in the osmometer. It is probable that a similar change does not occur in the body. It seems remarkable, however, that concentration of the protein was sufficient to abolish lability of pressure in such hypoproteinemic sera. Other factors, such

${ }^{3}$ Filtration was carried out with a Zsigmondy ultrafiltration apparatus (Pfaltz and Bauer Inc., New York) and an albumin proof ultrafine filter No. 1128. The filtrate obtained was water clear, of $\mathrm{pH} 8$ and had a specific gravity of 1.014 . 
as alteration in $\mathrm{pH}$ of the serum during the period of equilibration, require further investigation in this connection.

It is evident that measurement of the colloid osmotic pressure at the end of twenty or twentyfour hours gives only an approximate idea of the total pressures which hypoproteinemic sera are capable of developing. In general, the lower the concentration of protein the less representative will be the twenty-four readings. $A: G$ ratios appear to have had little or no effect upon the development of maximum pressures. On the other hand, ratios below one seem to have been more frequently associated with low pressures at the end of twenty-four hours than higher ratios. However, the number of pathological sera which were observed during the full twenty-four hour period were too few to permit correct interpretation of this finding.

\section{SUM MARY}

1. The colloid osmotic pressure of serum protein has been determined by a type of osmometer which permits observations of the pressure to be made at any desired interval of time, and which insures sterility of the serum.

2. Once the colloid osmotic pressure of serum having a normal concentration of protein was developed it was found to remain constant for sixteen to eighteen hours.

3. The colloid osmotic pressures of pathological sera with low concentrations of protein were found to be unstable. After rising to a maximum during the course of three to five hours the pressure began to fall gradually.

4. The reduced stability of the colloid osmotic pressure of hypoproteinemic sera was reproduced experimentally by dilution of normal serum with physiological saline or with the ultrafiltrate from normal serum.

5. Concentration of the proteins of hypoproteinemic sera to 6 per cent or above by ultrafiltration resulted in a colloid osmotic pressure curve indistinguishable from that of normal serum.

\section{BIBLIOGRAPHY}

1. Govaerts, P. M., Recherches cliniques sur le rôle de la pression osmotique des protéines du sang, dans la pathogénie des oedèmes et de l'hypertension arterielle. Bull. Acad. roy. de méd. de Belgique, 1924, 4, 161.

2. Baráth, E., Klinische Beiträge zum Verhalten des onkotischen (kolloidosmotischen) Druckes. Ztschr. f. klin. Med., 1930, 114, 702.

3. Cope, C. L., The osmotic pressure of the blood proteins in nephritis. Quart. J. Med., 1928, 22, 91.

4. Peters, J. P., Bruckman, F. D., Eisenman, A. J., Hald, P. N., and Wakeman, A. M., The plasma proteins in relation to blood hydration. VI. Serum proteins in nephritic edema. J. Clin. Invest., 1931, 10, 941.

5. Kylin, E., Studien über den kolloid-osmotischen (onkotischen) Druck. XXXI. Ztschr. f. d. ges. exper. Med., 1934, 93, 480.

6. Wells, H. S., Youmans, J. B., and Miller, D. G., Jr., A formula and nomogram for the estimation of the osmotic pressure of colloids from the albumin and total protein concentrations of human blood serum. J. Clin. Invest., 1933, 12, 1103.

7. Wells, H., Miller, D. G., Jr., and Drake, B. M., The validity of rapid determinations of the osmotic pressure of protein solutions. J. Clin. Invest., 1935, $14,1$.

8. Hammerschlag, A., Eine neue Methode zur Bestimmung des specifischen Gewichtes des Blutes. Ztschr. f. klin. Med., 1892, 20, 444.

9. Howe, P. E., The determination of proteins in blood -a micro method. J. Biol. Chem., 1921, 49, 104.

10. Fellows, M. D., Determination of colloid osmotic pressure of blood serum. Proc. Soc. Exper. Biol. and Med., 1932, 29, 1175.

11. Verney, E. B., The osmotic pressure of the proteins of human serum and plasma. J. Physiol., 1926, 61, 319.

12. Weech, A. A., Snelling, C. E., and Goettsch, E., The relation between plasma protein content, plasma specific gravity and edema in dogs maintained on a protein inadequate diet and in dogs rendered edematous by plasmapheresis. J. Clin. Invest., 1933, 12, 193.

13. Oelkers, H. A., Hormonale Beeinflussung des kolloidosmotischen Druckes. Arch. f. exper. Path. u. Pharmakol., 1931, 160, 9.

14. Bonsmann, M. R., Verhalten des kolloidosmotischen Druckes und der Eiweissfraktionen im Serum auf der Hohe der Tonephinwirkung beim Hunde. Arch. f. exper. Path. u. Pharmakol., 1932, 164, 211.

15. Tada, S., and Nakazawa, F., Hormonale Beeinflussung des kolloidosmotischen Drucks des Blutes. Tohoku J. Exper. Med., 1930, 15, 119.

16. Grönwall, A., Ueber die Bedeutung des Verhältnisses zwischen Bluteiweisskonzentration und dem sogenannten kolloid-osmotischen Druck. Biochem. Ztschr., 1935, 276, 223.

17. Drinker, C. K., and Field, Madeleine E., Lymphatics, lymph and tissue fluid. Williams and Wilkins, Baltimore, 1933, pp. 63-64. 